JCCA Volume 5, Issue 1, Spring 2018

\title{
Contemporary Chinese Artists in the Globalised Art World
}

\author{
Editorial
}

Jiang Jiehong

The end of the Chinese Cultural Revolution opened an entirely new chapter for modern Chinese history, and certainly, for Chinese art too. China opened its door to the rest of the world, but it did not happen over night. In the late 1970 and 1980s, there was still a lot of oppression in China with only a limited range of knowledge or information available. Within such a circumstance, a dynamic avant-garde movement took place in this resistance of all the difficulties, and an incredible group of artists emerged and became to China what the $1960 s$ cohort including Andy Warhol and Joseph Beuys was to America and Europe. ${ }^{1}$ This group of artists formed as a new generation of artists for China, who are committed to break the boundaries of 'Chinese art', and to extend their artistic and cultural understandings to the world.

There are two sides of the factors, external and internal, for the development of Chinese contemporary art from local to global. Since the last decade of the twentieth century, externally, Chinese art started to attract the world's attention by artists' frequent participations in the international exhibitions. Notably, in 1993, as a section of the $45^{\text {th }}$ Venice Biennale, Passaggio a Oriente (Passage to the Orient) marked one of the first appearances of Chinese contemporary art on the international art stage presenting fourteen Chinese artists. ${ }^{2}$ Since then, Chinese contemporary art has been frequently contributing to those long-standing art events of biennials, triennials and art fairs, in cities like Venice, Kassel, São Paulo, Basel, Istanbul, Sydney and many more. Numerous survey shows of contemporary art from China have been introduced to the West in the early 1990s, for instance, Art Chinois 1990: Chine Demain pour Hier (1990) in Aix-en-Provence in France, and China Avant Garde (1993-94), first opened in Berlin, and subsequently travelled to

${ }_{1}$ Obrist, Hans Ulrich, Ai Weiwei Speaks: with Hans Ulrich Obrist. London: Penguin, 2011, pp. 77-8.

2 Passagio a Oriente at the $45^{\text {th }}$ Venice Biennale (14 June - 10 October 1993) was curated by Achille Bonito Oliva with Helena Kontova. As an earlier example, Gu Dexin, Huang Yongping and Yang Jiecang participated in the international exhibition, Les Magiciens de la Terre, curated by Jean-Hubert Martin at the Pompidou Centre in Paris. 
Rotterdam, Oxford, Odense and Hildesheim ${ }^{3}$. Chinese contemporary art, all in a sudden, became a new club member of the western art world. In the last two decades, it had been invited by important museums, galleries and institutions, to name a few, Inside Out: New Chinese Art (1999), at San Francisco Museum of Modern Art, The Real Thing: Contemporary Art from China (2007) at the Tate Liverpool, New World Order: Contemporary Installation Art and Photography from China (2008) at the Groninger Museum in Groningen, The Revolution Continues: New Art from China (2008) at the Saatchi Gallery and Art of Change: New Directions from China (2012) at Hayward Gallery in London, and most recently Art and China after 1989: Theatre of the World (2017), the Solomon R. Guggenheim Museum, New York. These exhibitions, as commonly understood, 'not only uphold cultural diversity as a locus of resistance to the universalising tendencies of western colonialism/imperialism, but also the conspicuous translation/hybridising of cultural influences involved in the making of internationalised contemporary art as a performative rejoinder to all forms of cultural essentialism'.$^{4}$

Internally, by the end of the 1990s, as well as continuing to promote the merits of economic well being, cultural development was also picked up as one of the strategies to enhance China's entry into the World Trade Organization in 2001. Contemporary art exhibitions in China started to welcome international artists from the beginning of this millennium, marked by the third Shanghai Biennale, precisely, in 2000. Following the success of the first two editions of the Shanghai Biennale $(1996,1998)$, major contemporary art events were considered as an alternative opportunity to connect China to the world. ${ }^{5}$ Although it aims to be international, its title - Shanghai Spirit (or in Chinese Haishang, Shanghai) - appears to be perfectly local, or indeed, as a port of departure to the world. According to the press release, 'it is through Shanghai that China observes and accepts the western culture and the West understands and enters China ... Today, Shanghai has participated in the globalising trends with its special glamour and become more than a city in its geometrical sense to people in the world. Shanghai Spirit not only aims to discuss the cultural identity of the city, but also the possibility of accepting other contemporary art and cultures to intensify its

\footnotetext{
3 See Koch, Franziska (2011), "China" on Display for European Audiences? The Making of an Early Travelling Exhibition of Contemporary Chinese Art - China Avant Garde (Berlin/1993), available at http://heiup.uniheidelberg.de/journals/index.php/transcultural/article/view/9129/3103 [accessed on 18 January 2018]. 4 Gladston, Paul, Deconstructing Contemporary Chinese Art: Selected Critical Writings and Conversations, 20072014, Berlin: Springer, 2015, p. 22.

5 Wang, Yanyan, Creating A New Urban Life: A Critical Study of the Educational Significance of the Shanghai Biennale, PhD thesis, Birmingham City University, 2017, pp. 112-9.
} 
development. ${ }^{6}$ At these platforms established in China, more Chinese artists can exhibit their work with those from different cultural background and become part of the international art world. In addition to the Chinese government's awareness and anxiety about the internationalisation of cultural and creative industries through urban transformations, and the institution of biennials and triennials invented and boomed in various cities in China, the rise of newly founded private art museums and successful galleries has also played a part in promoting Chinese artists and the development of contemporary art in the international context.

In its early development, Chinese contemporary art was recognised in the West merely as a symbol of the existence of free individual spirit within the structure of collectivism, so the work labelled as Cynical realism (wanshi xianshi zhuyi) and Political Pop (zhengzhi bopu) have been representative on the international platform. ${ }^{7}$ Or, through the baptism of the Cultural Revolution, new art have been developed in conjunction with the examination of the iconography of Mao, the colour red, the textual image of the big-character posters and the rebellious spirit. ${ }^{8}$ At the same time, in a way, 'Chinese artists as the "other" are purely "aestheticized" [as] an exotic object, rather than an individual whose contribution to international cultural exchanges is approached in an active and most valuable way. ${ }^{9}$ And today, during the development of international art events within and beyond China, other alternatives arise and evolve. For example, cultural traditions have been a mine of particular energy, an energy that empowers a kind of 'uniqueness' for art production. While this 'uniqueness of a work of art is inseparable from its being imbedded in the fabric of tradition $^{10}$, this strategy becomes vital for Chinese contemporary art in the context of globalisation, to challenge the existing models in the westernised intellectual and everyday life. ${ }^{11}$

\footnotetext{
${ }^{6}$ Available at http://cn.cl2000.com/exhi/shanghai2000/zongshu.shtml [accessed 19 January 2013].

$7 \mathrm{Pi}$, Li, 'Between Scylla and Charybdis: the New Context of Chinese Contemporary Art and its Creation since 2000', in Waling Boers and Pi Li (eds.), Touching the Stones: China Art Now, Hong Kong: Timezone 8, 2007, pp. $82-7$.

8 Jiang, Jiehong, The Revolution Continues: New Art from China, London: the Saatchi Gallery and Jonathan Cape, 2008.

9 Hou, Hanru, 'Entropy, Chinese Artists, Western Art Institutions: A New Internationalism', in Yu Hsiao-Hwei (ed.), On the Mid-Ground, Hou Hanru, Hong Kong: Timezone 8, 2002, p. 58.

${ }^{10}$ Benjamin, Walter, 'The Work of Art in the Age of Mechanical Reproduction', in Hannah Arendt (ed.), Harry Zohn (trans.), Illuminations, New York: Schocken Books, 1969.

${ }^{11}$ The relationship between Chinese contemporary art and traditional arts and culture will be discussed by a series of paper in a special double edition (JCCA 6.2\&3), Everyday Legend: Reinventing Traditions in Chinese Contemporary Art, to be published in autumn 2019.
} 
There are two immediate examples, both staged in the international arena, and both significant, to observe the current situations of Chinese artists in the contemporary art world. Frist, the latest edition of China Pavilion, Continuum - Generation by Generation (in Chinese term, buxi), curated for the $57^{\text {th }}$ Venice Biennale (2017). In response to the overarching theme Viva Arte Viva, the curator led two pairs of artists and artisans to present a body of collaborative works, discovering the approach to pursue 'eternity' in Chinese culture. ${ }^{12}$ It attempted to set up a dialogue between crafts and art, the traditional and the contemporary, and between the local and the international, and yet, the communications appear to be debatable or sometimes interrupted with lack of subtlety in the process of 'translation'. Secondly, the recent Guggenheim exhibition of Chinese contemporary art, as mentioned earlier, presented work by some 70 Chinese artists. These Chinese artists, As stated by the curatorial team, 'have been both critical observers and agents of China's emergence as a global presence and places their experiments firmly in a global art-historical context' and, their 'provocations aim to forge reality free from ideology, to establish the individual apart from the collective, and to define contemporary Chinese experience in universal terms'. ${ }^{13}$ This exhibition revisits the two important decades in the development of Chinese contemporary art and seemingly, it follows the fashion of earlier curatorial expedition from the West, in Geremie Barmé's words, 'to celebrate too readily vacuous critiques of capitalism, to unearth supposed acts of resistance in artistic gestures, and to extol experimental forays as rebellions in miniature ${ }^{114}$. Leaving alone the use of animals in the artwork, that aroused the heated debates on animal rights (as well as human rights), what's new brought to us by the curatorial proposition, if any, to rethink Chinese contemporary art and its artists in the global context?

The term 'Chinese' in JCCA is always cultural and signals a broad sense, to include artists not only from Mainland China, but also Hong Kong, Taiwan, as well as those global Chinese diasporas. Through the open call, the making of this issue is special - it is curatorial and editorial at the same time. From a variety of perspectives, through artistic lives, political, cultural and creative strategies and methodological approaches, this issue has included

\footnotetext{
${ }_{12}$ Curated by Qiu Zhijie, this pavilion presented works by contemporary artists Tang Nanan and Wu Jian'an, as well as two state-level craftsmen respectively of shadow puppets and Su embroidery, Wang Tianwen and Yao Huifen.

${ }_{13}$ Exhibition press release, 2017, available at https://www.guggenheim.org/press-release/guggenheim-presentsart-and-china-after-1989-theater-of-the-world-opening-october-6-2017 [accessed on 25 January 2018]. ${ }_{14}$ Barmé, Geremie, China's Art of Containment, 2017, available at http://www.nybooks.com/daily/2017/11/27/chinas-art-of-containment/ [accessed on 25 January 2018].
} 
papers discussing six important artists as a series of case studies, namely, Ai Weiwei, Cao Fei, Chen Chieh-Jen, Xu Bing, Zhang Peili and Zheng Guogu. Although there is no way to include all important artists more comprehensively as we wished, these individuals and their work are discussed here as representative examples of development of Chinese contemporary art responding to the globalised art world today. Lastly, we would like to take this opportunity to thank our invited co-editor Dr Wenny Teo of this particular edition for her collaboration and invaluable contribution. 